\title{
HUBUNGAN SELF EFFICACY DAN AXIENTY DENGAN HASIL TENDANGAN PENALTI
}

Ervan Kastrena1, Agung Praseptiana2,Sandi3

1Program Studi PJKR Universitas Suryakancana Cianjur, Indonesia 2 Program Studi PJKR STKIP Purwakarta, Indonesia

3Program Studi PJKR Universitas Suryakancana, Cianjur, Indonesia ervankastrena@unsur.ac.id prasetiaagung021@gmail.com

Info Artikel

Diterima Agustus 2019

Disetujui November 2019

Dipublikasikan Desember 2019

\section{Abstrak}

Tujuan penelitian ini adalah untuk mengetahui hubungan antara self efficacy dan axienty dengan hasil tendangan penalti. Metode penelitian yang digunakan adalah deskriptif korelasi. Populasi dalam penelitian ini adalah mahasiswa yang mengikuti unit kegiatan mahasiswa sepakbola di Fakultas Keguruan dan ilmu Pendidikan berjumlah 30 mahasiswa. Instrumen yang digunakan adalah angket self efficacy dan axienty serta tes menendang bola ke gawang dengan angka sasaran dari Nurhasan (2007). Analasis data menggunakan SPSS versi 19 dengan taraf signifikansi 0,05 (5\%). Hasil penelitian menunjukkan bahwa: (1) terdapat hubungan antara self efficacy dengan hasil tendangan penalti $(\mathrm{r}=524)$ (2) terdapat hubungan axienty dengan hasil tendangan penalti $(\mathrm{r}=348)$ (3) terdapat hubungan secara simultan antara self efficacy dan axienty dengan hasil tendangan penalti $(r=531)$. Kesimpulan bahwa koefisien korelasi antara self efficacy dan axienty dengan hasil tendangan penalti berkorelasi sedang.

Keyword:

Self Efficacy, Axienty,

Abstrack

Tendangan Penalti

The purpose of this study was to determine the relationship between self efficacy and axienty with penalty kick results. The research method used is descriptive correlation. The population in this study were students who participated in the football student activity unit in the Teaching and Education Faculty totaling 30 students. The instrument used was a self efficacy and axienty questionnaire and a kicking ball at goal with a target score from Nurhasan (2007). Data analysis used SPSS version 19 with a significance level of 0.05 (5\%). The results showed that: (1) there was a relationship between self efficacy and penalty kick results ( $r$ = 524) (2) there was an axienty relationship with penalty kick results $(r=348)$ (3) there was a simultaneous relationship between self efficacy and axienty with penalty kick results $(r=531)$. The conclusion is that the correlation coefficient between self efficacy and axienty with the penalty kick results is moderately correlated

(C) 2019 Universitas Suryakancana

$\square$ Alamat korespondensi:

E-mail:

Adirahadian@unsur.ac.id
e-ISSN : xxxx-Xxxx (online)

p-ISSN : 2089-2341 (cetak) 


\section{PENDAHULUAN}

Olahraga sepakbola merupakan salah satu cabang olahraga yang paling diminati dan yang mempunyai popularitas yang sangat tinggi di kalangan masyarakat. Olahraga sepabola hampir dimainkan di semua negara, bahkan di Indonesia sepakbola di mainkan oleh seluruh lapisan masyarakat dari anak-anak sampai orang tua, dan sering dimainkan mulai dari desa sampai kota besar.

Dalam permainan sepakbola atlet dituntut harus bisa mengusai semua teknik dasar yang ada dalam permainan sepakbola terutama dalam hal shooting atau tendangan penalti. Penalti adalah tendangan atau tembakan hukuman karena melanggar peraturan permainan didaerah depan penjaga gawang pada batas yang ditentukan. In soccer, the execution of 'dead ball' skills such as free kicks, throw ins, corner kicks, and penalty kicks to determining the overall result of a game (Hazell, 2014:1). Tidak jarang seorang pemain mengalami sebuah kecemasan dan timbulnya rasa tidak yakin terhadap kemampuan yang dimilikinya ketika menghadapi tendangan penalti, apalagi dalam tekanan yang tinggi dari supporter lawan. Tendangan penalti yang didapatkan oleh sebuah tim harus dimanfaatkan sebaik mungkin, artinya ketika seorang pemain dapat mencetak gol, maka akan memberikan keuntungan pada timnya tersebut. Secara umum, tendangan penalti dianggap menguntungkan bagi tim yang mendapatkannya, oleh karena itu pemain sering merasa cemas saat melakukan eksekusi penalti dan akibatnya sering gagal dan tidak sesuai dengan apa yang diharapkan (Horikawa \& Yagi, 2012).faktor lain seperti motor ability memiliki korelasi tinggi dengan keterampilan siswa pada tingkatan SMA (Kastrena et al, 2018). Untuk dapat melakukan tendangan penalti, bukanlah suatu hal yang mudah, karena membutuhkan faktor psikologis atau mental yang kuat.

Kebanyakan para pelatih saat ini, hanya memfokuskan pada perkembangan fisik, teknik dan taktik semata. Artinya aspek mental sering kali terbaikan atau dianggap tidak terlalu penting. Senada dengan pendapat Harsono (2015) menyatakan bahwa "Kesalahan umum para pelatih kita adalah bahwa aspek psikologis yang sangat penting artinya itu, sering diabaikan atau kurang diperhatikan pada waktu melatih, oleh karena mereka selalu hanya menekankan pada latihan guna penguasaan teknik, taktik serta pembentukan keterampilan yang sempurna". Aspekaspek mental tersebut perlu dilatih dan dikelola dengan baik, karena dalam pertandingan, aspek mental memiliki pengaruh $80 \%$ dan $20 \%$ untuk aspek lain (Harsono (2015:3). Dilandasi oleh penjelasan tersebut, apa yang terjadi sesuai dengan fakta dilapangan, dimana berdasarkan hasil observasi dan informasi 
dari mahasiswa dari mahasiswa unit kegiatan mahasiswa di Fakultas Keguruan dan Ilmu Pendidikan Universitas Suryakancana bahwa pelatih UKM sepakbola hanya berfokus untuk mengembangkan faktor kondisi fisik, teknik dan taktik atlet semata dan tidak pernah sama kali memberikan latihan mental, padahal menurut Harsono (2015:101) bahwa "Perkembangan mental atlet tidak kurang pentingnya dari perkembangan ketiga faktor tersebut, sebab betapa sempurnapun perkembangan fisik, teknik dan taktik atlet, apabila mentalnya tidak turut berkembang prestasi tinggi tidak mungkin akan dapat dicapai."

Lemahnya mental atlet tersebut terlihat ketika atlet tidak yakin dengan kemampuan yang dimilikinya hingga menimbulkan rasa cemas saat akan bertanding seperti ingin buang air kecil, tidak tenang, gelisah, dll. Selain itu, permasalahan lebih jauh ketika atlet dihadapkan dengan esekusi tembakan penalti hampir $80 \%$ bola yang ditendang tidak pernah masuk dan $20 \%$ nya dapat ditangkap dengan mudah oleh penjaga gawang. Terkait dengan permasalahan tersebut, peneliti berasumsi bahwa hal itu terjadi karena faktor keyakinan diri atlet yang rendah sehingga menimbulkan tingkat kecemasan yang tinggi dalam diri atlet. Dengan kata lain, faktor self-efficacy dan kecemasan (axienty) sangat menentukan terhadap keberhasilan dalam melakukan tembakan penalti.

Self-efficacy diartikan sebagai keyakinan seseorang untuk mampu menjalankan tugas tertentu dengan sukses (Feltz \& Lirgg, 2001:2). Hasil penelitian Hashemi \& Ghanizadeh (2011:2) menunjukan prestasi akademis siswa dipengaruhi oleh keyakinan yang mereka pegang mengenai kemampuan untuk mengorganisasikan dalam menyelesaikan sebuah tugas.

Tingkat self-efficacy yang baik atau tinggi sangat penting dalam permainan sepak bola dan telah menjadi fokus utama sebagai salah satu faktor paling signifikan yang mempengaruhi kinerja dalam sebuah permainan (Cotterill et al 2010). Dampak positif dari self-efficacy yang baik, memungkinkan atlet dapat mengurangi tingkat kecemasannya (Hazell, Cotterill \& Hill, 2014:2). Artinya self-efficacy pada diri atlet perlu diperhatikan dan dikelola dengan sebaik mungkin.

Faktor lain yang turut berkorelasi dengan hasil tendangan penalti yaitu kecemasan. Kecemasan atau anxiety yaitu perasaan takut, cemas, atau khawatir terancam kepribadiannya (Harsono, 2015:265). Sebenarnya, kecemasan terjadi pada saat emosi ketika menghadapi esekusi tembakan penalti, hal itu terjadi karena kekhawatiran pemain terhadap hasil akhir yang diperoleh atau masuk tidaknya bola yang ditendang (Jordet \& Gemser, 2012). Peneliti 
mengangap bahwa penelitian ini penting untuk dilakukan karena melalui penelitian ini, nantinya akan diperoleh suatu informasi atau data terkait hubungan antara selfefficacy dan axienty terhadap penampilan atlet ketika melakukan tendangan penalti, sehingga pelatih dapat membuat suatu program latihan mental sebagai upaya meningkatkan keyakinan diri dan mengurangi kecemasan pada diri atlet.

Berdasarkan latar belakang dan analisis masalah yang telah diungkapkan di atas, maka penelitian ini bertujuan untuk mencari informasi lebih detail terkait korelasi antara self-efficacy dan axienty dengan hasil tendangan penalti.

\section{METODE}

Dalam penelitian ini, peneliti mengunakan metode penelitian korelasi. Metode penelitian analisis korelasi dipilih karena akan mempelajari hubungan dua variabel atau lebih, yakni hubungan variasi dalam satu variabel dengan variasi dalam variabel lain (Arifin, 2011:48). Populasi yang digunakan dalam penelitian ini yaitu mahasiswa yang mengikuti unit kegiatan mahasiswa sepak bola di Fakultas Keguruan dan Ilmu Pendidikan Universitas Suryakancana, yang berjumlah 32 orang. Teknik sampling yang digunakan dalam penelitian ini yaitu purvosive sampling. sampel dalam penelitian ini adalah mahasiswa UKM sepak bola yang berjumlah 30 orang. Instrumen untuk mengukur self-efficacy dan anxiety yang dimiliki oleh mahasiswa dapat menggunakan kuesioner. Kemudian instrumen tendangan penalti dalam permainan sepak bola yaitu menendang bola ke target sasaran. Analisis data menggunakan SPSS versi 19.

\section{HASIL dan PEMBAHASAN}

Berdasarkan Model Summary bahwa besarnya hubungan antara self-efficacy dan axienty terhadap hasil tendangan penalti menunjukan korelasi sebesar 0.531 berarti terdapat hubungan dalam katagori sedang. Pada dasarnya self-efficacy maupun axienty keduanya merupakan aspek dalam ilmu psikologis yang sangat penting bagi mental mahasiswa, di mana self-efficacy berfungsi untuk menumbuhkan perasaan yakin terhadap kemampuan yang dimiliki oleh seorang atlet, sedangkan axienty rendah berfungsi untuk menampilkan kemampuan terbaik atau secara optimal.

\section{SIMPULAN}

Simpulan dalam penelitian ini, bahwa untuk dapat menghasilkan tendangan penalti yang efektif sangat berkaitan erat dengan self-efficacy yang berfungsi untuk memunculkan sebuah keyakinan pada diri atlet terkait kemampuan yang dmilikinya, sehingga atlet tersebut mampu melaksanakan tendangan penalti dengan sebaik mungkin. Sedangkan axienty juga turut memberikan dampak terdapat baik dan 
tidaknya tendangan yang dilakukan, semakin tinggi tingkat kecemasannya, semakin tinggi pula atlet tersebut akan melakukan sebuah kesalahan. Seperti yang dijelaskan oleh Jordet \& Gemser, (2012) kecemasan terjadi pada saat emosi ketika menghadapi esekusi tembakan penalti, hal itu terjadi karena kekhawatiran pemain terhadap hasil akhir yang diperoleh atau masuk tidaknya bola yang ditendang.

\section{DAFTAR PUSTAKA}

Arifin, Zainal. (2011). Penelitian Pendidikan.

Cotterill, S. T., Sanders, R., \& Collins, D. (2010). Developing effective preperformance routines in golf: Why don't we ask the golfer? Journal of Applied Sport Psychology, 22(1), $51-64$.

doi:10.1080/10413200903403216.

Feltz, D. L., \& Lirgg, C. D. (2001). Self Efficacy Belief Of Athletes, Teams, And Coaches. In R. N. Singer, H. Hausenblas, \& C. Janelle, Handbook of Sport Psychology (pp. 340-361). New York: John Wiley \& Sons.

Harsono. (2015). Kepelatihan Olahraga. Bandung : PT. Remaja Rosdakarya.

Hashemi M R. (2011). Emotional Intelligence and Self-Efficacy: A Case of Iranian EFL University Students. International Journal of
Linguistics ISSN 1948-5425 2011, Vol. 3, No. 1: E29.

Hazell J, et al (2014). An exploration of preperformance routines, self-efficacy, anxiety and performance in semiprofessional soccer. European Journal of Sport Science, 2014. Vol. 00, No. 00, 1-8,

Horikawa M, Yagi A. (2012). The Relationships among Trait Anxiety, State Anxiety and the Goal Performance of Penalty Shoot-Out by University Soccer Players. PLoS ONE $\quad 7(4): \quad$ e35727. doi:10.1371/journal.pone.0035727.

Jordet, G., \& Hartman, E. (2008). Avoidance motivation and choking under pressure in soccer penalty shootouts. Journal of Sport \& Exercise Psychology, 30(Bandung: PT Remaja Rosdakarya.

Kastrena, et al. (2018). Correlation between Motor Ability and Long Jump Skills of Students. Proceedings of the 4th International Conference on Sport Science, Health

Muhamad Syamsul Taufik, (2019),Hubungan Tingkat Konsentrasi Dengan Keterampilan Bermain Futsal Unit Kegiatan Mahasiswa Futsal Universitas Suryakancana Jurnal Gladi: Jurnal 
102| Ervan Kastrena1, Agung Praseptiana2,Sandi3

Hubungan Self Efficacy Dan Axienty Dengan Hasil Tendangan Penalti

Ilmu Keolahragaan Jilid 10

Terbitan 02 Halaman 68-78

Physical Education (ICSSHPE 2018).

Atlantis Press. 
